\title{
KEPEDULIAN LINGKUNGAN DAN KESEHATAN DI CONDONGSARI BANYUURIP PURWOREJO
}

\author{
Affan Luthfi Fahmi Hakim ${ }^{1}$, Ari Prasetyo ${ }^{2}$, Solikin Andriyanto ${ }^{3}$, Syamsul Hadi ${ }^{3}$ \\ ${ }^{1}$ Ilmu Sastra Indonesia Fakultas Ekonomi dan Bisnis Universitas Sebelas Maret \\ ${ }^{2}$ Teknik Mesin Sekolah Vokasi Universitas Sebelas Maret \\ ${ }^{3}$ Teknik Mesin Fakultas Teknik Universitas Sebelas Maret \\ syamsulhadi@ft.uns.ac.id
}

\begin{abstract}
Abstrak
Condongsari merupakan salah satu desa di Kabupaten Purworejo, Provinsi Jawa Tengah. Desa Condongsari merupakan salah satu desa sasaran Universitas Sebelas Maret dalam pelaksanaan Kuliah Kerja Nyata (KKN) periode Januari-Februari 2021. Pelaksanaan KKN tersebut mengusung tema "Pengembangan Kepedulian Lingkungan dan Kesehatan di Desa Condongsari, Kecamatan Banyuurip, Kabupaten Purworejo". Tema tersebut dirasa sesuai untuk pengembangan desa dengan tetap memperhatikan kondisi siaga di tengah wabah pandemi Covid-19. KKN UNS telah menyelesaikan 6 program kerja utama dan 6 program kerja penunjang dalam bidang kebersihan, kesehatan, pendidikan, multimedia, pertanian, dan literatur. Seluruh program telah terlaksana dengan baik dengan tetap menerapkan protokol kesehatan secara ketat. Partisipasi masyarakat dan pemerintah Desa Condongsari sangat baik dalam merespon program kegiatan yang dilaksanakan oleh Tim KKN UNS. Semua program utama dan penunjang yang telah terealisasi diharapkan dapat mengoptimalkan potensi yang dimiliki Desa Condongsari. Setiap kegiatan yang telah berlangsung secara kontinyu diharapkan agar tetap dipertahankan sebagai bekal bagi masyarakat Desa Condongsari untuk mengembangkan potensi desa di tengah kondisi normal baru pasca pandemi Covid-19. Program yang telah terlaksana diharapkan dapat memberikan kontribusi yang bersifat membangun bagi Desa Condongsari.
\end{abstract}

Kata Kunci: KKN, Condongsari, Hidroponik, Toga, Kokedama

\section{PENDAHULUAN}

Kabupaten Purworejo terletak di bagian selatan pulau Jawa yang berbatasan dengan Provinsi Daerah Istimewa Yogyakarta. Kabupaten tersebut terletak pada posisi $1.034,81752 \mathrm{~km}^{2}$. Administrasi wilayah ini dibagi dalam 16 kecamatan, 25 kelurahan, dan 469 desa. Banyuurip sebagai salah satu kecamatan di Kabupaten Purworejo berjarak 15 menit dari pusat kota. Di wilayah administrasi Banyuurip ini terdapat 27 desa/kelurahan, salah satu desa tersebut yaitu Condongsari. Di desa Condongsari terbagi menjadi empat dusun yang melingkupi 19 rukun tangga. Desa ini berbatasan dengan Kelurahan Kledung Kradenan di sebelah Utara, Desa Candisari di sebelah Barat, Desa Boro \begin{tabular}{l|l} 
Lingkungan Hidup dan Kebencanaan & 614
\end{tabular} 
Kulon di sebelah Timur dan Desa Candingasinan di sebelah Selatan. Desa Condongsari termasuk desa dengan penduduk yang cukup padat. Terdapat 4 perumahan yang berada di desa tersebut.

Dalam peninjauan di lapangan, desa ini memiliki beberapa permasalahan seperti tempat pembuangan sampah yang terbatas sehingga banyak sampah berserakan dan tidak terkelola dengan baik. Selain itu, kurangnya pengelolaan sampah dari hasil limbah rumah tangga masyarakat Desa Condongsari. Hal tersebut terjadi karena minimnya upaya pemanfaatan limbah, khususnya limbah organik. Limbah organik tersebut dapat dijadikan pupuk kompos, sedangkan untuk limbah anorganik dapat digunakan untuk produk-produk daur ulang (Sulistyorini, 2005; Amaranti dkk, 2016; Nurjazuli dkk, 2016; Sahil dkk, 2016; Buhani dkk, 2018; Hadiwidodo dkk, 2018; Sudiro dkk, 2018; Ismail, 2019; Mardwita dkk, 2019; Trahutami, 2019; Mahmudah dkk, 2020; Muntafail dkk, 2020; dan Shitophyta dkk, 2021;).

Disamping masalah yang terjadi, komoditas pertanian di Desa Condongsari sangat potensial. Upaya budidaya menanam cenderung cocok diterapkan di Desa Condongsari. Beberapa metode dan teknik budidaya modern dirasa mampu dalam memaksimalkan potensi pertanian sebagai komoditas unggulan Desa Condongsari seperti Kokedama (Septriani dkk, 2019; Fajriani dkk, 2021; Sari dkk, 2021; dan Yuliarti dkk, 2021). Pengelolaan komoditas pertanian dengan mengikuti perkembangan teknologi diharapkan dapat menjadikan produksi dari komoditas pertanian tetap dapat berdaya saing di tengah modernisasi. Masalah lain yang terjadi adalah kurangnya kegiatan produktif yang dilakukan masyarakat Desa Condongsari sehingga membuat kegiatan yang seharusnya dapat dilakukan kegiatan padat karya menjadi kurang terealisasi.

Kuliah Kerja Nyata (KKN) yang merupakan program pengabdian masyarakat dari Universitas Sebelas Maret (UNS) sudah dilakukan secara rutin dari tahun ke tahun. Progam KKN UNS sudah banyak membantu memberdayakan masyarakat dalam bidang ekonomi, pendidikan, kesehatan, dan lingkungan guna membantu masyarakat dalam pembangunan desa (Hadi dkk, 2019 dan Hadi dkk, 2020) bahkan pada masa pandemi COVID-19 juga (Dewi dkk, 2019; Rohmah dkk, 2019; Rosalinda dkk, 2019; dan Sabrina dkk, 2019).

\section{METODE}

Kegiatan KKN UNS dilaksanakan pada 12 Januari 2021 sampai dengan 25 Februari 2021 melalui duabelas program kerja yang terbagi dalam 6 program kerja utama dan 6 program kerja penunjang. Program kerja terdiri dari Pengelolaan Sampah, Pengolahan Sampah (Pembuatan Kompos), Bimbingan Belajar Luring, Pembuatan Masker Hias, Sosialisasi Normal Baru, Pemanfaatan Media Sosial, Hidroponik, Toga (Tanaman Obat Keluarga), Kokedama, Bimbingan Belajar Daring, Pembuatan Buku Profil Desa, dan Pembangunan Gudang Keranda Metode yang digunakan untuk melaksanakan pengabdian adalah identifikasi permasalahan dengan survey ke lapangan, diskusi dan penyusunan rencana kerja dengan masyarakat dan pembimbing, pelaksanaan rencana kerja dan evaluasi serta laporan.

\section{HASIL DAN PEMBAHASAN}

\section{Pengelolaan Sampah}

Pada masa pandemi, produksi sampah rumah tangga semakin meningkat. Hal ini disebabkan adanya anjuran pemerintah untuk tetap di rumah saja demi memutus rantai penyebaran Covid-19. Oleh karena itu, untuk meminimalisir dampak buruk dari banyaknya sampah. Pemilahan adalah salah satu langkah pertama dalam pengelolaan sampah sedangkan pengolahan sampah berikutnya dapat berupa pengolahan menjadi pupuk kompos.

Program Pengelolaan Sampah adalah kegiatan untuk memberikan pengertian dan praktek bagi masyarakat desa Condongsari untuk membagi antara sampah organik dan anorganik agar masyarakat dapat membedakan dalam proses pembuangan akhir sampah tersebut dan juga menyortir sampah sampah yang dapat didaur ulang kembali. Kegiatan ini dimulai dengan membeli ember yang besar untuk dijadikan tempat sampah. Tahap selanjutnya yaitu pengecatan ember dengan

Lingkungan Hidup dan Kebencanaan 615 
tulisan 'KKN UNS' dan keterangan jenis sampah. Terakhir tempat sampah di distribusikan ke tempat yang strategis.

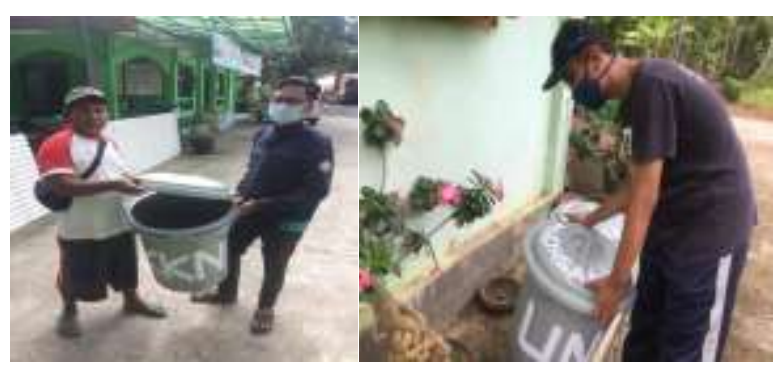

Gambar 1. Penyerahan dan peletakan tempat sampah kepada warga di Masjid Nurul Jannah dan rumah kepala Desa Condongsari

Hasil yang dicapai kesadaran masyarakat akan kebersihan lingkungan meningkat dan masyarakat dapat memilah jenis sampah sehingga diharapkan sampah dapat dimanfaatkan semaksimal mungkin. Warga Desa Condongsari antusias dalam kegiatan pengelolaan sampah dan kepala desa juga memberikan dukungan terhadap kegiatan tersebut dan mengarahkan bagaimana sistem pembagian dan penempatan bak sampah yang akan disebar di Desa Condongsari.

\section{Pengolahan Sampah Kompos)}

(Pembuatan

Setelah program pemberian pengertian dan praktek tentang pemilahan sampah progam berikutnya yang dilakukan adalah pengolahan sampah yang berisi program pengolahan sampah menjadi kompos. Pembuatan kompos bermanfaat untuk mengurangi dampak yang ditimbulkan dari banyaknya sampah organik. Kompos bermanfaat untuk meningkatkan kesuburan tanah dan memperbaiki lingkungan. Pengembangan pembuatan kompos akan berguna dalam jangka panjang untuk lingkungan yang lebih baik. Bahan dasar pembuatan pupuk kompos yang akan digunakan yaitu sampah rumah tangga. Selain mengurangi pencemaran lingkungan, tentu kegiatan ini akan menambah nilai dari sampah itu sendiri. Program kerja akan dilaksanakan bersama masyarakat Desa Condongsari dengan harapan masyarakat mendapatkan feedback positif dari kegiatan ini.

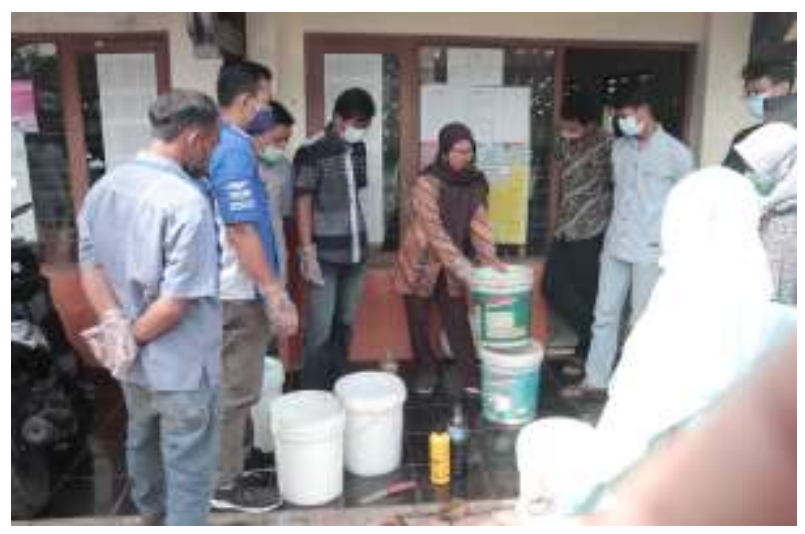

Gambar 2. Penjelasan mengenai pembuatan komposting oleh penyuluh dari Balai Penyuluh Pertanian (BPP)

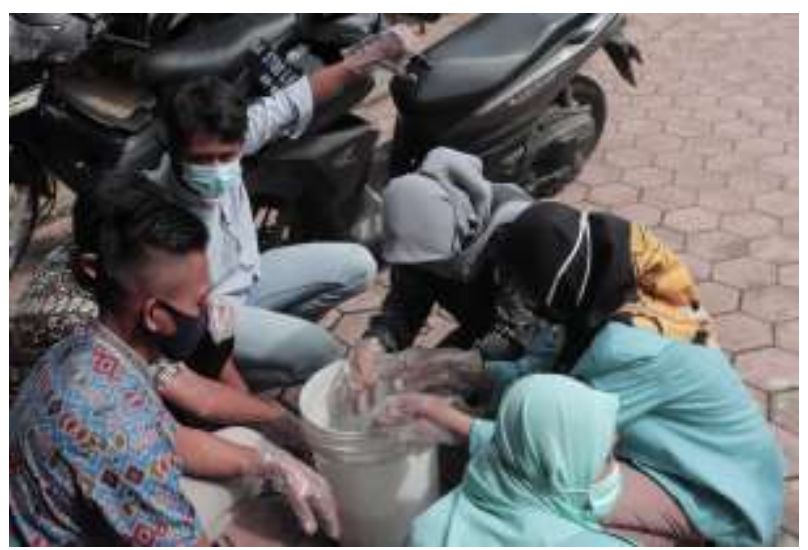

Gambar 3. Praktik pembuatan kompos dengan karang taruna di Balai Desa Condongsari

Kegiatan pengelolaan sampah (pembuatan kompos) dilakukan di aula balai desa Condongsari. Dengan narasumber mahasiswa KKN dan juga penyuluh dari BPP Banyuurip dengan mengundang karang taruna sebagai peserta kegiatan. Kegiatan berupa materi dari narasumber dilanjutkan dengan praktik pembuatan kompos. Kegiatan dapat dilakukan dengan lancar karena tempat yang memadai, adanya bantuan dari BPP Banyuurip meskipun terjadi keterlambatan waktu acara karena kedatangan peserta kurang tepat waktu, serta kurang koordinasi antara tim KKN dengan BPP tentang narasumber yang mengisi acara tetapi program berhasil memberikan hasil dimana peserta dapat memahami bagaimana mengolah sampah organik menjadi kompos. Partisipasi masyarakat dalam hal Lingkungan Hidup dan Kebencanaan 616 
ini anggota Karang Taruna sudah baik karena sebagian besar sudah berpartisipasi dalam praktik pembuatan kompos serta aktif dalam berdiskusi saat penyampaian materi.

\section{Bimbingan Belajar Luring}

Kegiatan bimbingan belajar offline merupakan salah satu program kerja utama dari Tim KKN UNS di Dusun Condong kulon, Desa Condongsari yang bertujuan untuk membantu siswa/i belajar selama pandemi Covid-19. Selama kegiatan belajar, siswa/i dapat berkonsultasi mengenai materi pelajaran yang belum dipahami. Selain itu, siswa/i juga dapat belajar sambil bermain sehingga menumbuhkan rasa semangat belajar agar tidak mudah bosan. Sasaran dari program ini adalah siswa/i yang sedang menempuh pendidikan sekolah dasar. Program ini telah dilakukan setiap hari Sabtu, namun beberapa kali kegiatan ini terpaksa ditiadakan karena anjuran pemerintah mengingat masa pandemi. Siswa/i di Dusun Condong Kulon berjumlah dua puluh lima anak. Lokasi yang digunakan untuk melakukan kegiatan Belajar Bersama adalah dengan menggunakan rumah salah satu penduduk yang sudah tidak berpenghuni, yang terletak bersebelahan dengan rumah Kepala Desa Condongsari. Program kerja Belajar Bersama dilakukan sebanyak empat kali dengan berbagai kegiatan sesuai dengan tema dan pembelajaran yang diinginkan.

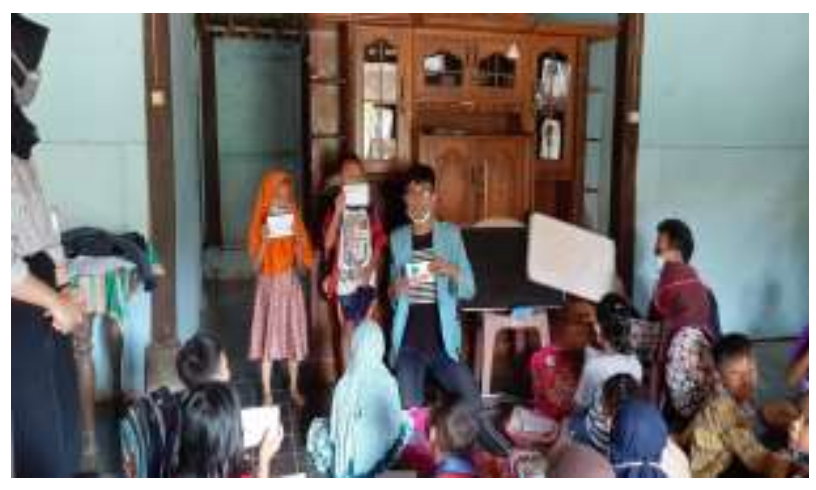

Gambar 2. Praktik pembuatan kompos dengan karang taruna di Balai Desa Condongsari

Program kerja Belajar Bersama terdiri dari beberapa kegiatan yaitu: mengerjakan tugas/PR, seni melipat kertas/origami, menggambar, bernyanyi, dan nonton bareng. Faktor yang mendukung suksesnya acara ini adalah ketersediaan tempat dan fasilitas belajar, antusiasme siswa/i, dan ikut berperannya karang taruna. Hasil yang didapat dari kegiatan ini adalah siswa/i dapat memahami bahwa belajar bisa dilakukan dimanapun dan dengan cara apapun meskipun situasi pandemi. Selain membantu siswa/i mengerjakan tugas, kegiatan ini juga membantu siswa/i mengisi waktu luang mereka dengan kegiatan yang positif seperti menggambar, mewarnai, maupun bermain kreativitas. Beberapa alat tulis yang dibagikan akan bermanfaat untuk siswa/i di Condongsari untuk terus belajar. Partisipasi karang taruna dalam kegiatan belajar bersama sangatlah baik, mereka ikut berkontribusi dalam kegiatan ini. Antusiasme siswa/i di Desa Condongsari juga luar biasa baik, terlihat dari setiap kegiatan yang dilakukan terus dihadiri oleh siswa/i tersebut. Bahkan, ada beberapa orang tua yang mengantarkan anaknya belajar bersama di posko KKN.

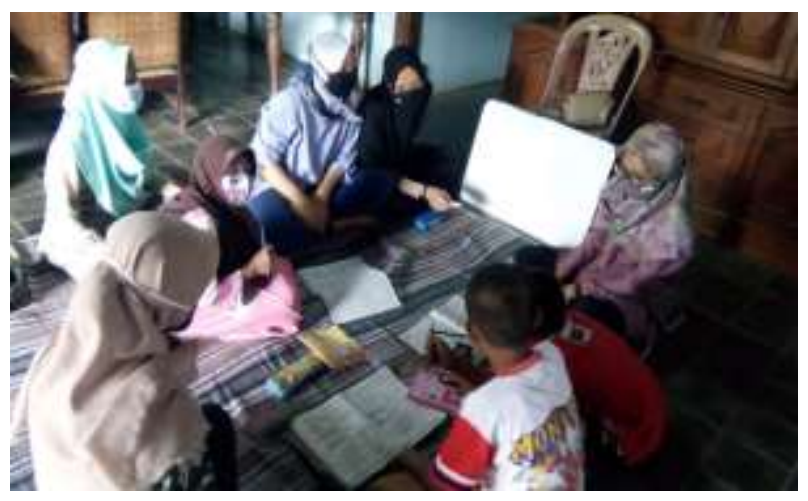

Gambar 3. Pendampingan belajar luring dengan anak-anak sekolah dasar di posko KKN.

\section{Pembuatan Masker Hias}

Pandemi COVID-19 masih belum berakhir sehingga masyarakat diharapkan untuk tetap mempertahankan kesadaran dan pola hidup yang sesuai dengan protokol kesehatan. Salah satu bentuk protokol kesehatan dan pencegahan penyebaran virus ini adalah dengan tetap menggunakan masker. Kini, masker kain buatan tangan menjadi kian populer sebab masker kain buatan tangan ini memiliki pola dan warna yang bervariasi dan dapat dipilih sesuai dengan selera. Selain itu, masker kain

Lingkungan Hidup dan Kebencanaan 617 
dapat dengan mudah dibuat sendiri dengan harga bahan-bahan yang terjangkau.

Program kerja sosialisasi dan pelatihan pembuatan masker hias ini bertujuan untuk mengedukasi masyarakat, terutama PKK Desa Condongsari, tentang bagaimana cara membuat masker kain yang sesuai dengan standar protokol kesehatan. Lebih lanjut, dengan menghias masker kain yang sudah selesai dibuat, diharapkan para peserta menjadi lebih kreatif dan inovatif dalam menciptakan value added sebuah produk. Nantinya, pembuatan masker kain dapat digunakan atau diperjualbelikan guna menambah perekonomian selama masa pandemi.

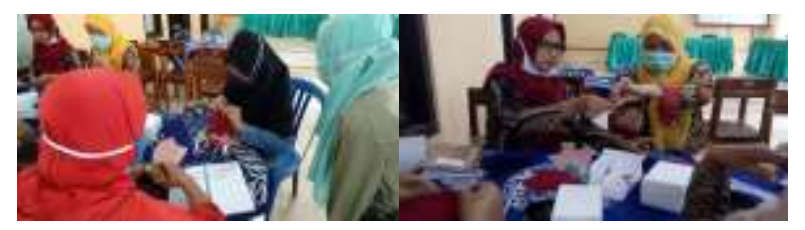

Gambar 4. Pembuatan masker bersama ibu-ibu PKK Desa Condongsari

Kegiatan ini dilakukan bersamaan dengan kegiatan perkumpulan rutin anggota PKK Desa Condongsari. Kegiatan ini disambut dengan baik oleh PKK Desa Condongsari yang menjadi peserta kegiatan ini. Selain itu, antusiasme peserta yang tinggi dalam mengikuti setiap rangkaian kegiatan menjadi pendukung bagi kelancaran pelaksanaan kegiatan. Lokasi pelaksanaan terletak di Balai Desa Desa Condongsari dengan akses yang mudah dijangkau yang mana seluruh peserta sudah mengetahui tempat tersebu. Faktor penghambat yang terjadi adalah ketidak tepatan waktu peserta hadir seerta kurangnya persiapan atau latihan dari pihak anggota KKN yang berperan sebagai pembantu atau pendamping bagi peserta kegiatan. Hasil yang dicapai dari kegiatan ini adalah telah terlaksanannya kegitan untuk mengedukasi masyarakat terutama PKK Desa Condongsari tentang bagaimana cara membuat masker kain buatan tangan yang sesuai dengan protokol kesehatan (SNI), menumbuhkan inovasi dan kreativitas para peserta dalam menciptakan nilai tambah di sebuah produk. Kegiatan ini diikuti oleh PKK Desa Condongsari, baik dari pengurus maupun anggota, dengan semangat. Hal ini dapat dilihat dari antusiasme peserta dalam mengikuti kegiatan. Mereka juga tidak sungkan untuk bertanya apabila ada yang kurang dimengerti dan memberikan saran yang konstruktif, misalnya adalah saran untuk menggunakan jenis benang tertentu agar mendapat hasil jahitan yang lebih bagus.

\section{Sosialisasi Normal Baru (New Normal)}

Tujuan dari kegiatan ini adalah untuk berbagi ilmu dengan masyarakat, meningkatkan kewaspadaan masyarakat terhadap Covid-19, dan meningkatkan wawasan mengenai vaksinasi Covid19. Harapan dari diadakannya kegiatan tersebut adalah agar masyarakat desa mengetahui dan paham bagaimana tata cara melaksanakan normal baru dan vaksinasi Covid-19 agar tetap dapat melaksanakan kegiatan ekonomi tanpa was-was terkena Covid-19.

Alasan pemilihan protokol new normal dan vaksinasi Covid-19 sebagai topik pembahasan karena pelaksanaan normal baru masih sering diabaikan dan maraknya rumor atau hoax yang beredar mengenai vaksinasi Covid-19 terutama di lingkungan pedesaan seperti di Desa Condongsari. Warga pedesaan sepertinya masih kurang pengetahuan mengenai tata cara normal baru dan vaksinasi Covid-19. Masyarakat desa dewasa ini lebih mudah menerima informasi dikarenakan mayoritas sudah memakai smartphone dan jaringan internet. Namun hal tersebut jarang dibarengi dengan tingkat literasi yang baik sehingga sering termakan isu dan berita hoax yang membuat masyarakat itu was-was mengenai vaksinasi Covid19.

Sosialisasi protokol new normal dan vaksinasi Covid dihadiri oleh Kepala Desa Condongsari, tenaga kesehatan Puskesmas Banyuurip, Sekretaris Desa, Ketua LPM Desa Condongsari, Ketua RW, Ketua RT, Kepala Dusun, dan Ketua Karang taruna Desa Condongsari. Acara dimulai dengan sambutan oleh Kepala Desa Condongsari. Sosialisasi ini merupakan salah satu wujud kegiatan tim KKN Tematik UNS yang bertujuan untuk meningkatkan kewaspadaan terhadap Covid-19 dan pemahaman terhadap vaksinasi Covid-19 di Desa Condongsari.

Faktor yang mendukung keberhasilan program ini adalah vaksinasi Covid-19 sedang ramai diperbincangkan, dan tak jarang membuat masyarakat was-was karena rumor yang beredar,

\begin{tabular}{l|l} 
Lingkungan Hidup dan Kebencanaan & 618
\end{tabular} 
Juga karena masyarakat desa mayoritas bekerja di bidang pertanian sehingga harus keluar rumah dan sering bergotong-royong dalam mengelola lahan pertanian sehingga tokoh masyarakat di desa biasanya lebih dipercaya dalam menyampaikan informasi oleh masyarakat. Di samping itu partisipasi warga yang aktif dan keterbukaan warga dalam menerima masukan dan informasi baru memudahkan pemerintah desa yang cukup paham mengenai pentingnya protokol kesehatan dan vaksinasi Covid-19 menyampaikan informasi penting ke warganya. Tetapi ada sedikit keterbatasan yang terjadi karena kegiatan di era pandemi ini dibatasi maksimal 25 orang peserta, sehingga belum dapat mengundang tokoh masyarakat desa secara keseluruhan, dikarenakan ruangan tidak cukup luas untuk memberi jarak 1 meter per peserta, sehingga jarak antar peserta hanya kurang lebih $50 \mathrm{~cm}$.

Hasil yang dicapai dari kegiatan ini adalah tokoh dan masyarakat Desa Condongsari paham mengenai protokol new normal dan vaksinasi Covid-19 sehingga masyarakat desa mampu meningkatkan kewaspadaan terhadap Covid-19 serta keadaan ekonomi dapat membaik pasca pandemic dan diharapkan tokoh masyarakat dapat menyebarkan ilmu yang telah didapat kepada seluruh bagian masyarakat di Desa Condongsari

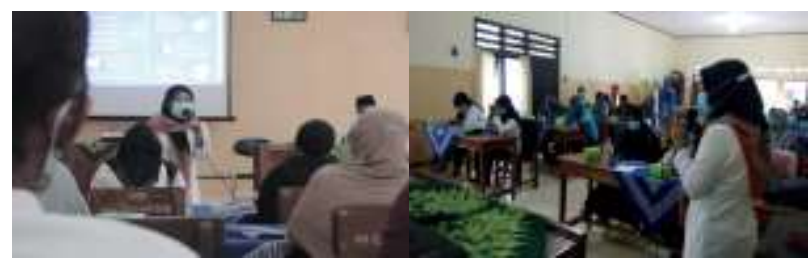

Gambar 2. Penyampaian materi sosialisasi mengenai protokol new normal

Partisipasi tokoh masyarakat sangat antusias, dibuktikan dari seluruh peserta menghadiri undangan yang diberikan. Hal tersebut sudah menandakan jika masyarakat desa sudah memiliki rasa keingintahuan mengenai protokol new normal dan vaksinasi Covid-19. Ditambah partisipasi dari Dinas Kesehatan diwakili oleh Ibu Zumrotul Chomariyah, S.KM., M.PH dan Ragil Wiwik Setyaningsih, S.KM selaku tenaga kesehatan dari Puskesmas Banyuurip sehingga materi yang disampaikan sesuai dengan bidangnya dan dapat dipertanggungjawabkan.

\section{Pemanfaatan Media Sosial}

Dalam dunia komunikasi, media sosial bermanfaat sebagai sarana untuk membangun hubungan atau relasi. Bahkan media sosial membantu kita untuk berkomunikasi jarak jauh karena media sosial memiliki jangkauan global. Media sosial mempermudah kita untuk berinteraksi di manapun kita berada. Selain komunikasi, media sosial juga berfungsi sebagai media informasi.

Di era pandemi Covid-19, penggunaan media sosial dapat menjadi alternatif untuk melakukan komunikasi dan penyebaran informasi. Informasi yang disampaikan dapat dijangkau tidak hanya dari masyarakat Desa Condongsari melainkan masyarakat luas yang menggunakan media sosial.

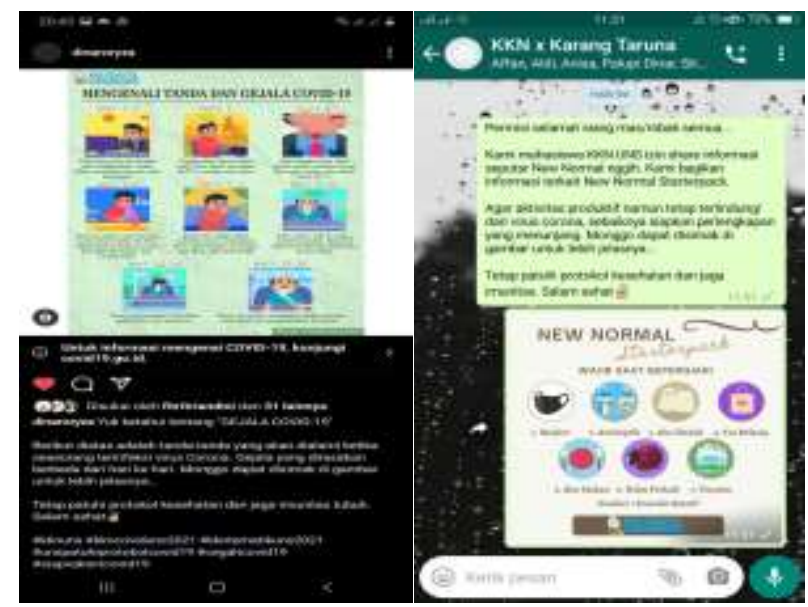

Gambar 2. Share informasi mengenai Covid 19 di media sosial

Program kerja ini berupa unggahan berita, tips dan trik untuk membantu masyarakat menghadapi kebiasaan normal baru. Tidak hanya hanya itu, informasi lainnya juga dapat menjadi sumber pengetahuan. Faktor pendukung progam ini berjalan dengan lancara adalah mudahnya mencari informasi yang terbaru, jaringan yang bagus untuk mengakses internet, dan penyebaran informasi dapat berjalan dengan cepat. Faktor penghambat yang terjadi adalah sedikitnya anggota yang bisa mendesain sehingga proses pembuatan memakan waktu yang lama sehingga berpengaruh terhadap terlambatnya waktu pengunggahan konten. Hasil yang dicapai adalah semua konten yang sudah direncanakan dapat diunggah dan disebarluaskan

Lingkungan Hidup dan Kebencanaan 619 
kepada masyarakat Desa Condongsari khususnya dan masyarakat umum pada umumnya sehingga dapat memberikan pengetahuan kepada warga Desa Condongsari seputar pandemi covid-19, dan menumbuhkan kesadaran warga Desa Condongsari setelah membaca konten yang diunggah. Masyarakat sangat antusias terutama anggota Karang Taruna yang terbukti dengan respon dari anggota ketika ada mahasiswa KKN yang mengunggah konten. Selain itu konten yang diunggah di media massa juga mendapat insight yang sangat bagus dengan banyaknya jumlah orang yang melihat dan menyukai konten yang diunggah.

\section{Hidroponik}

Budidaya Tanaman Hidroponik merupakan salah satu program KKN yang bertujuan memanfaatkan lahan pekarangan rumah untuk dijadikan lahan pertanian tanaman hidroponik guna menghasilkan tanaman dengan keuntungan antara lain tidak memerlukan lahan yang luas, mudah dalam perawatan, memiliki nilai jual yang tinggi. Program KKN ini dapat menambah pengetahuan baru untuk masyarakat serta pemanfaatan hasil tanam untuk konsumsi pribadi atau dapat dijual untuk bisnis. Budidaya Tanaman Hidroponik menjadi peluang usaha baru bagi masyarakat. Menjadikan tanaman hidroponik sebagai alternatif dari penanaman sayuran dengan cara konvensional.

Kegiatan ini diawali dengan penjabaran materi mengenai hidroponik dan tata cara pembuatan. Setelah penjabaran selesai, kemudian dilaksanakan pembuatan hidroponik bersama anggota karang taruna. Pembuatan hidroponik ini dilaksanakan selama dua hari. Pada hari pertama kegiatan yang dilakukan yaitu membuat kerangka dan melubangi pipa paralon. Kegiatan sempat terhenti karena ada visitasi dari LPPM UNS. Pada hari kedua kegiatan yang dilakukan yaitu menyambungkan pipa-pipa, saluran air, dan memastikan tidak ada air yang bocor atau keluar dari pipa. Faktor pendukung yang menyukseskan program kegiatan adalah posko KKN yang strategis sehingga banyak anggota karang taruna yang hadir, bahan dan peralatan mudah didapatkan, serta antusias dan semangat yang tinggi pada peserta kegiatan.
Hasil yang dicapai adalah meningkatnya pengetahuan anggota Karang Taruna mengenai teknik penanaman secara hidroponik, masyarakat dapat memanfaatkan lahan kosong untuk hidroponik serta menumbuhkan kreativitas dan gotong royong karang taruna pada saat pembuatan hidroponik. Partisipasi peserta pada kegiatan ini sudah baik. Semua peserta baik dari tim KKN dan karang taruna saling membantu dalam pembuatan hidroponik. Pemerintah desa juga turut memberikan dukungan dalam bentuk penyediaan tempat pelaksanaan kegiatan hidroponik.

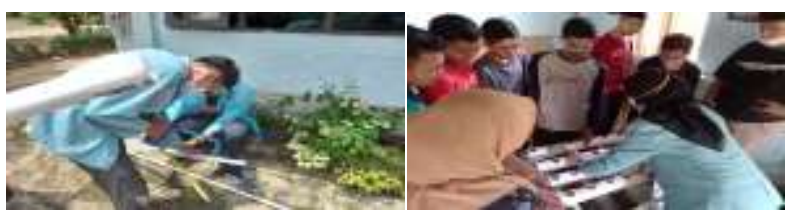

Gambar 2. Pembuatan hidroponik bersama karang taruna

\section{Toga (Tanaman Obat Keluarga)}

Pandemi Covid-19 yang masih melanda membuat masyarakat mengurangi aktivitas di luar rumah. Selain itu, selama pandemi Covid-19 setiap masyarakat diharapkan memiliki sistem kekebalan tubuh atau imun yang tinggi untuk mencegah penularan virus tersebut. Peningkatan sistem kekebalan tubuh bisa dilakukan dari rumah dengan mengonsumsi obat-obat tradisional yang ada di rumah.

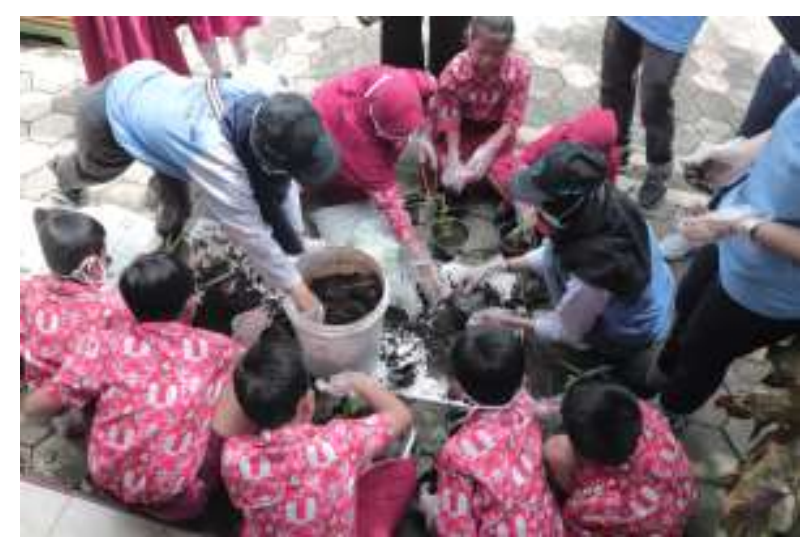

Gambar 2. Pembuatan tanaman obat keluarga (toga) bersama siswa kelas 4 SD Negeri Condongsari

Lingkungan Hidup dan Kebencanaan 
Tanaman Obat Keluarga (TOGA) adalah tanaman budidaya di rumahan yang berkhasiat sebagai obat. Tanaman obat ini bisa digunakan sebagai obat tradisional yang dapat menyembuhkan beberapa penyakit. Obat tradisional lebih aman dikonsumsi daripada obat kimia walaupun lebih cepat efek yang ditimbulkan oleh obat kimia. Menanam tanaman obat ini tidak membutuhkan lahan yang luas karena mereka tidak tumbuh amat besar bisa menggunakan polybag atau pot kecil. Selain untuk obat, tanaman ini bisa digunakan untuk menghias rumah agar lebih sejuk dan segar.

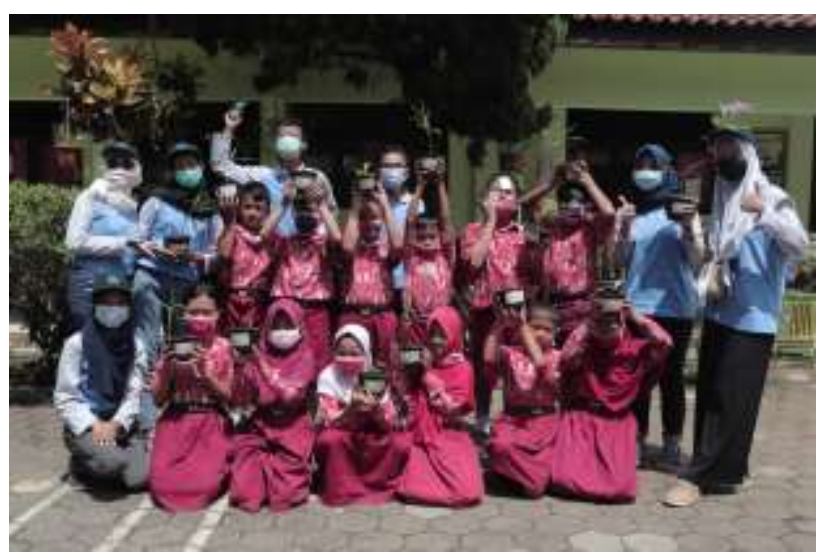

Gambar 2. Hasil tanaman tanaman obat keluarga (toga)

Kegiatan ini dilakukan di halaman depan SD Negeri Condongsari dengan sasaran siswa-siswi SD Negeri Condongsari. Program dimulai dengan penyampaian materi secara singkat oleh Tim KKN UNS kemudian praktik menanam langsung di halaman depan. Program ini diharapkan dapat menjadi alternatif untuk pemenuhan obat yang lebih aman bagi masyarakat terutama di tengah pandemi Covid-19 ini. Faktor Pendukung: Pandemi Covid19 yang mengharuskan di rumah saja dan memiliki imun yang tinggi, Siswa-siswi SDN Condongsari sebagai ujung tombak gerakan menanam Tanaman Obat Keluarga (TOGA). Faktor Penghambat: Kurangnya partisipan karena kegiatan pembelajaran dilakukan secara terbatas hanya beberapa siswasiswi saja yang datang ke sekolah, Pemilihan waktu yang kurang tepat, membuat beberapa siswa-siswi sudah ada yang dijemput oleh orang tua untuk pulang ke rumah.

Hasil yang dicapai adalah siswa-siswi SDN Condongsari menjadi tahu mengenai manfaat dari beberapa tanaman obat yang ada di lingkungan mereka dan bisa mereka gunakan, menumbuhkan kesadaran bagi siswa-siswi SDN Condongsari pentingnya menanam Tanaman Obat Keluarga (TOGA) di rumah, dan mengedukasi siswa-siswi SDN Condongsari tentang bagaimana cara menanam dan merawat Tanaman Obat Keluarga (TOGA) di rumah.

Kegiatan ini diikuti oleh siswa-siswi SDN Condongsari dengan antusiasme yang cukup tinggi. Siswa-siswi SDN Condongsari dengan semangat mempraktekan langsung cara menanam Tanaman Obat Keluarga (TOGA). Mereka juga aktif menanggapi saat diLakukan penyampaian materi dan mau menjawab pertanyaan yang diajukan oleh Tim KKN UNS untuk mengulas kembali materi yang disampaikan. Kepala SDN Condongsari memberikan kesempatan yang lebar bagi Tim KKN UNS untuk melaksanakan kegiatan tersebut dengan membantu menyebarkan undangan kegiatan melalui wali kelas untuk disampaikan kepada wali siswa.

\section{Kokedama}

Salah satu kegiatan KKN UNS di Desa Condongsari adalah Kokedama. Kokedama ini merupakan sebuah kegiatan bercocok tanam terutama tanaman hias yang memiliki akar serabut dengan menggunakan media tanam berupa bola tanah yang ditutupi oleh moss (lumut) atau dapat diganti dengan sabut kelapa, tanpa adanya pot. Sebelumnya teknik menanam yang tergolong unik ini diperkenalkan oleh Jepang, yang mana awalnya berupa kombinasi nearai bonsai dan gaya menanam kusamono dengan tanaman yang digunakan adalah tanaman bonsai.

Kegiatan ini ditujukan untuk Anggota PKK yang sebagian besar adalah ibu-ibu rumah tangga. Dari latar belakang anggota PKK yang mayoritas ibu rumah tangga, kegiatan ini diharapkan dapat menjadi ide untuk lahan usaha disamping meningkatkan kreativitas dan inovasi anggota PKK. Sehingga, hal ini dapat menunjang peningkatan keterampilan dan kesejahteraan masyarakat di Desa Condongsari. Kegiatan kokedama ini diawali oleh penjelasan dari panitia penyelenggara yakni mahasiswa KKN UNS melalui pemutaran video pembuatan kokedama. Setelah pemutaran video usai, anggota PKK dipersilahkan untuk membuat tanaman hias kokedama yang dipandu atau dibantu oleh mahasiswa KKN UNS. Dan diakhir kegiatan

Lingkungan Hidup dan Kebencanaan 621 
ini, hasil dari pembuatan kokedama yang dilakukan oleh anggota PKK dapat dibawa pulang oleh masing-masing peserta.

Faktor yang mendukung program dapat berjalan dengan baik adalah alat dan bahan mudah didapatkan seperti tanaman hias, sabut kelapa, benang kasur, tambang, dan gunting. Hal ini juga ditunjang dengan keadaan geografis Desa Condongsari sehingga banyak pohon kelapa tumbuh, yang mana memudahkan untuk menyiapkan sabut kelapa dalam jumlah besar, Alat dan bahan memiliki nilai ekonomi yang rendah atau murah. Tetapi setelah diolah menjadi tanaman hias berupa kokedama terdapat added value, sehingga nilai ekonomi menjadi lebih tinggi dari semulanya, Kepopuleran tanaman hias pada masa kini meningkatkan antusias peserta untuk membuat kokedama. Tetapi disamping itu ada faktor yang menghambat yaitu turunnya hujan yang sering terjadi sebelum pelaksanaan kegiatan sehingga mahasiswa KKN perlu menjemur sabut kelapa terlebih dahulu agar dapat digunakan dalam keadaan kering sehingga persiapan yang dilakukan oleh mahasiswa KKN UNS menjadi kurang maksimal dikarenakan acara kegiatan dilaksanakan pada pagi hari meskipun antusias ibu-ibu PKK sangat baik sehingga mahasiswa KKN kewalahan.

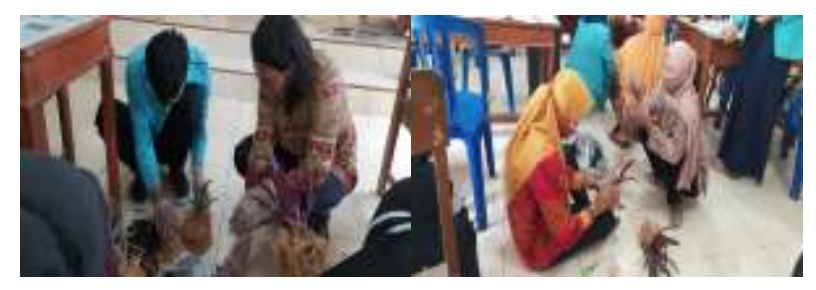

Gambar 2. Kegiatan Pembuatan Kokedama di Balai Desa Condongsari

Hasil yang diperoleh selama kegiatan adalah masyarakat melalui anggota PKK Desa Condongsari mengenal tentang teknik menanam Kokedama sehingga anggota PKK Desa Condongsari dapat meningkatkan kreativitas dan inovasi, dapat memanfaatkan sampah sabut kelapa yang terbengkalai tidak terpakai dan dapat dipakai sebagai lahan ide untuk berwirausaha.

Dari kegiatan kokedama yang telah dilakukan, masyarakat terutama anggota PKK yang sebagian besar adalah ibu-ibu rumah tangga ini sangat antusias dengan pembuatan tanaman hias kokedama. Hal ini dibuktikan dengan mahasiswa KKN UNS yang kewalahan untuk memandu acara dan membantu ibu-ibu PKK dalam pelaksanaan Bimbingan Belajar Daring pembuatan tanaman hias kokedama.

\section{Bimbingan Belajar Daring}

Program kegiatan Bimbingan Belajar Daring dilaksanakan untuk membantu siswa SD Negeri Condongsari. Bimbingan belajar daring (online) merupakan salah satu program kerja KKN UNS yang bertujuan untuk membantu para siswa khususnya siswa tingkat Sekolah Dasar (SD) dalam melakukan pembelajaran jarak jauh selama masa pandemi Covid-19. Pendampingan belajar online memfokuskan kepada anak-anak yang sedang menjalani sekolah di rumah dengan tugas-tugas sekolah yang dibebankan secara daring. Program pendampingan belajar online dilakukan untuk mendukung kegiatan proses belajar mengajar dengan menggunakan aplikasi Whatsapp dan dilakukan secara konsultasi online. Program pendampingan belajar online ini menjadi solusi bagi para siswa ketika menghadapi kendala dalam proses transfer ilmu atau pemahaman materi pembelajaran selama proses kegiatan belajar mengajar jarak jauh. Para siswa melakukan konsultasi secara online terkait tugas-tugas sekolah yang belum mampu mereka kerjakan sendiri kepada tim KKN UNS yang kemudian dibantu dengan memberikan langkah pengerjaan melalui video maupun foto.

Siswa SD yang berpartisipasi dalam program bimbingan belajar daring ini merupakan warga desa Condongsari yang bersekolah di SD Negeri Condongsari. SD Negeri Condongsari telah menerapkan kelonggaran dalam kebijakan kegiatan belajar mengajar jarak jauh. Para siswa sudah dapat masuk sekolah secara bergantian dengan total masuk sekolah selama 3 hari dalam seminggu. Kebijakan ini diterapkan dengan memperhatikan jumlah pertambahan kasus Covid-19 di Desa Condongsari dan tetap memperhatikan protokol kesehatan dalam pelaksanaannya. Di samping kelonggaran kebijakan tersebut, para siswa tetap mendapat tugas-tugas sekolah yang dibebankan secara daring. Oleh karena itu, tujuan dari program ini adalah untuk membantu para siswa SD dalam menyelesaikan tugas yang telah diberikan oleh Lingkungan Hidup dan Kebencanaan 622 
guru. Faktor pendukung yang membantu dalam pelaksanaan program ini adalah kebijakan kegiatan pembelajaran jarak jauh selama masa pandemi Covid-19, peran aktif Karang Taruna dalam membantu penyebaran informasi, akses komunikasi yang relatif mudah karena menggunakan aplikasi WhatsApp sehingga dapat dilakukan setiap saat. Sedangkan faktor penghambat program bimbingan belajar daring hanya dapat diikuti oleh siswa kelas 4 dan 5 SD, karena siswa SD belum banyak yang memiliki handphone pribadi

Hasil yang diperoleh dari program Bimbingan Belajar Daring adalah para siswa SD dapat mengerjakan tugas sekolah yang dianggap sulit apabila dikerjakan sendiri. Para siswa lebih mudah memahami langkah pengerjaan soal karena mendapat penjelasan dalam pengerjaan soal-soal melalui foto maupun video. Tindak lanjut yang diperlukan adalah dengan memotivasi para siswa untuk tidak malu dan sungkan dalam berkonsultasi terkait tugas-tugas yang diberikan oleh guru. Selain itu, para siswa diberikan langkah mudah dalam pengerjaan soal ketika melakukan konsultasi online agar pemahaman materi dapat tersampaikan dengan baik.

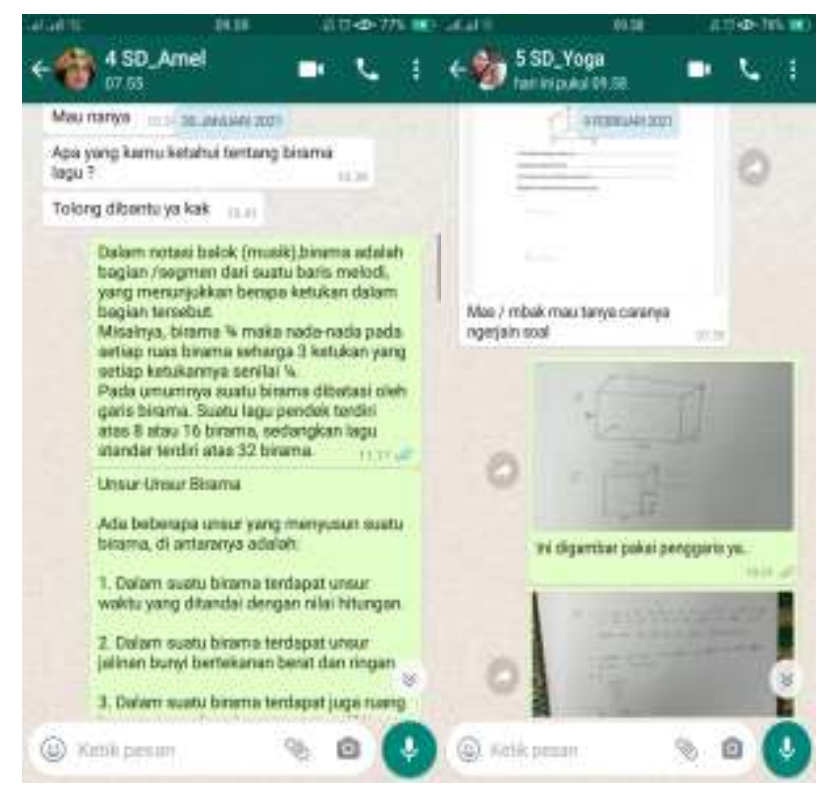

Gambar 2. Pendampingan belajar daring melalui media Whatsapp

Partisipasi dari masyarakat Desa Condongsari cukup baik dalam merespon program Bimbingan Belajar Daring. Kelompok Karang
Taruna juga turut andil dalam penyebaran informasi terkait program ini. Di samping itu, respon siswa dalam mengikuti program Bimbingan Belajar Daring juga lumayan baik dilihat dari partisipasi mereka ketika melakukan konsultasi online terkait tugas- tugas sekolah yang dilakukan beberapa kali.

\section{Pembuatan Buku Profil Desa}

Penyediaan informasi dilaksanakan melalui penyusunan buku profil desa dan kelurahan. Profil Desa dan Kelurahan menurut Peraturan Menteri Dalam Negeri Nomor 12 Tahun 2007 adalah gambaran menyeluruh tentang karakter desa dan kelurahan yang meliputi data dasar keluarga, potensi sumber daya manusia, kelembagaan, prasarana dan sarana serta perkembangan kemajuan dan permasalahan yang dihadapi desa dan kelurahan. Desa Condongsari merupakan salah satu desa yang ada di Kecamatan Banyuurip. Adapun jumlah penduduk sebanyak 1958 yang tersebar ke dalam tiga dusun. Sebagian besar penduduk bermata pencaharian sebagai petani.

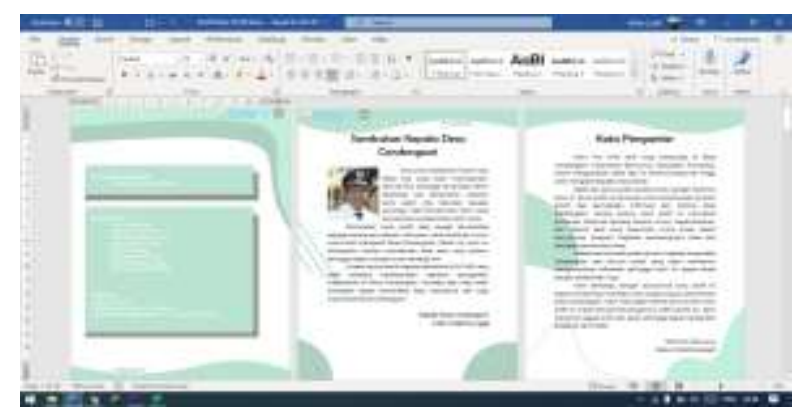

Gambar 2. Pembuatan Buku Profil Desa Condongsari

Berdasarkan temuan di lapangan diketahui bahwa Desa Condongsari sudah memiliki sebuah profil atau publikasi berupa laman/website. Namun laman tersebut belum terkelola dengan baik. Dengan disusunnya buku profil ini, diharapkan dapat menjadi salah satu acuan untuk memperbarui informasi yang ada di laman dan masyarakat dapat lebih mudah memperoleh informasi terkait kondisi kependudukan, dan potensi yang ada di Desa Condongsari. Pemerintah dan perangkat desa sangat antusias selama proses pembuatan buku ini. Terbukti jika terdapat informasi yang belum lengkap atau benar, maka akan melengkapi informasi tersebut. Faktor yang mendukung

Lingkungan Hidup dan Kebencanaan 623 
keberhasilan program ini adalah informasi mengenai Desa Condongsari sudah ada di dunia maya (internet) dan tersedianya buku Rencana Pembangunan Jangka Menengah (RPJM) Desa Condongsari. Hasil yang diperoleh adalah terciptanya buku profil Desa Condongsari sehingga warga menjadi lebih mengetahui informasi mengenai sejarah, potensi, dan data desa. Juga buku yang tersusun dapat menjadi sarana untuk promosi desa dan dapat menjadi dasar untuk pengembangan laman desa.

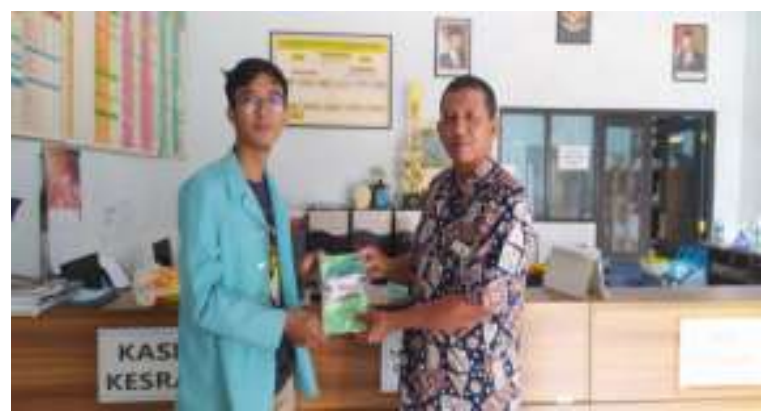

Gambar 2. Penyerahan Buku Profil Desa Kepada Kepala Desa Condongsari

\section{Pembangunan Gudang Keranda}

Pembangunan gudang keranda merupakan kolaborasi antara pemerintah desa dengan mahasiswa KKN dalam membangun fasilitas desa. Kegiatan ini dilakukan secara gotong royong oleh warga desa dan mahasiswa KKN. Kegiatan ini diawali dengan berdoa agar pembangunan dapat berjalan dengan lancar. Kemudian dilakukan makan pagi (sarapan). Setelah semua melakukan sarapan, kerja bakti mulai dilaksanakan dengan membagi beberapa titik pengerjaan. Titik tersebut dibagi berdasarkan tugas antara lain, membuat cakar ayam, meratakan tanah, memindahkan batu bata, membuat adonan semen, dll.

Pembangunan gudang keranda berfungsi sebagai tempat menyimpan keranda dan peralatan lainnya supaya terhindar dari panas dan hujan yang dapat merusak keranda. Selain itu pembangunan gudang dilaksanakan dalam rangka penunjang makam baru di dekat gudang tersebut. Faktor Pendukung: Banyaknya warga yang ikut berpartisipasi sehingga pekerjaan jadi lebih mudah dan cepat, Antusias warga sangat tinggi, terbukti ketika belum dimulai warga sudah mulai membersihkan sekitar gudang, Peralatan yang mendukung sehingga memudahkan dalam proses pembangunan. Faktor penghambat yant terjadi adalah banyaknya warga yang tidak menggunakan masker ketika kerja bakti membangun gudang keranda, terdapat anak kecil yang mengganggu mobilitas warga yang sedang kerja bakti, dan cuaca sangat terik sehingga banyak warga yang sering istirahat. Hasil yang dicapai dapat meningkatkan semangat gotong royong antar warga desa serta menambah fasilitas atau sarana dan prasarana Desa Condongsari.

Warga Desa Condongsari sangat antusias dalam kegiatan pembangunan gudang keranda. Warga desa melakukan kerja bakti dengan gotong royong untuk membangun salah satu fasilitas milik bersama. Banyak warga yang datang lebih awal dari jadwal yang sudah diberitahukan sebelumnya. Hal tersebut menjadi wujud semangat warga dalam membangun desa.

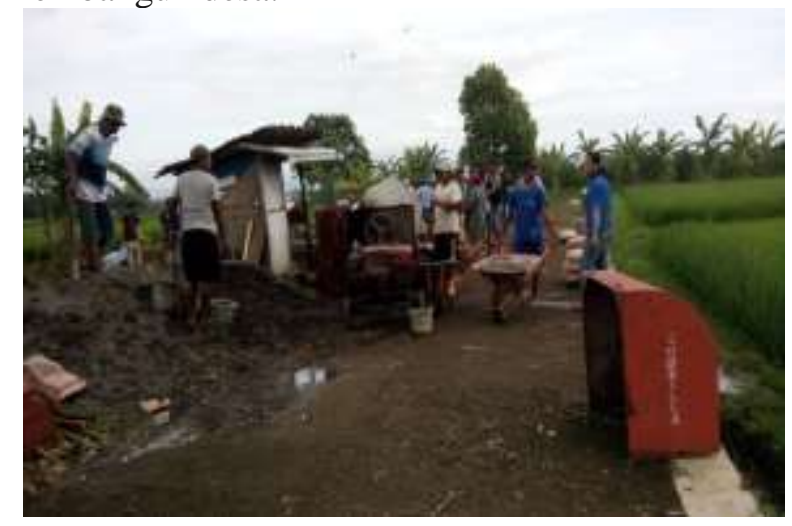

Gambar 2. Kerja Bakti Pembuatan Gudang Keranda

\section{KESIMPULAN}

Kegiatan Kuliah Kerja Nyata (KKN) yang merupakan salah satu bentuk sarana pengabdian kepada masyarakat di dunia nyata telah dilaksanakan oleh mahasiswa KKN Kelompok 48 Universitas Sebelas Maret Surakarta pada 12 Januari- 25 Februari 2021 oleh berlokasi di Desa Condongsari, Banyuurip Purworejo Jawa Tengah. Program kerja KKN di Desa Condongsari, Banyuurip, Purworejo, Jawa Tengah secara umum telah dilaksanakan dengan baik dan lancar karena 
adanya dukungan dari kepala desa, perangkat desa, dan masyarakat Desa Condongsari. Kegiatan KKN ini juga sudah didiseminasikan di laman http://purworejo news.com/berita/tim-kkn-uns-danpuskesmas-banyu urip-gelar-sosialisasi-vaksin/

Beberapa saran yang dapat diberikan baik untuk Pemerintah Desa Condongsari pemerintah setempat agar sekiranya dapat melanjutkan program-program yang telah terlaksana sehingga keberlanjutan dapat dirasakan manfaatnya oleh masyarakat, meningkatkan bekerja sama dalam menyusun konsep kegiatan KKN yang lebih sesuai dengan kondisi masyarakat serta menjaga semangat dalam pembangunan daerah yang lebih baik. Sedangkan untuk mahasiswa KKN UNS periode selanjutnya diharapkan untuk dapat lebih kreatif dan aktif dalam menemukan dan memecahkan permasalahan yang ada di masyarakat, menjaga komunikasi antara sesama anggota tim KKN UNS dan dengan masyarakat setempat maupun dengan perangkat pemerintah setempat, dapat lebih bersikap sopan dan santun selama masa kegiatan KKN serta kerja sama tim yang baik dalam setiap kegiatan yang dilakukan selama masa KKN berlangsung.

\section{UCAPAN TERIMAKASIH}

Ucapan terimakasih disampaikan kepada UP KKN LPPM UNS yang telah memberikan fasilitas terselenggaranya pengabdian mayasrakat ini, juga kepada bapak Cahyo Saptono, S. Si selaku Kepala Desa Condongsari dan ibu Zumrotul Chomariyah, S.KM., M.PH serta Ragil Wiwik Setyaningsih, S.KM selaku tenaga kesehatan dari Puskesmas Banyuurip sehingga KKN dan penyampaian materi dapat terselenggara dengan baik.

Ucapan terima kasih juga disampaikan kepada tijm pekasana KKN yant terdiri dari Affan Luthfi Fahmi Hakim, Siti Nur Ngulya Jamil, Palupi Dinar Oryza, Tika Sekar Kinasih, Aldi Pratama Seno Aji, Muhammad Muflikhan, Annisa Qhoirina, dan Betasari Ulfa Gatri.

\section{REFERENSI}

Amaranti, R., Achiraeniwati, E., As'ad, N., Nasution, A., dan M. Satori, 2016, Pendampingan
Masyarakat Dalam Pengolahan Sampah Organik Rumah Tangga Untuk Mendukung Program Urban Farming, Ethos (Jurnal Penelitian dan Pengabdian Masyarakat) 4 (2), 283-290

Buhani, Noviadi, R., dan Suharso, 2018,

Pengolahan Sampah Rumah Tangga Berbasis Partisipasi Aktif Dari Masyarakat Melalui Penerapan Metode 4Rp Untuk Menghasilkan Kompos, Sakai Sambayan - Jurnal Pengabdian kepada Masyarakat 2 (1), 7-13

Cahaya T. S., Nugroho, A., dan Dody, 2009, Pembuatan Kompos dengan Menggunakan Limbah Padat Organik (Sampah Sayuran dan Ampas Tebu), Teknik Kimia UNDIP.

Dewi, F. P., dan Hadi, S., 2019, Peningkatan Pemahaman Masyarakat Terhadap Covid-19 Di BTN Griya Nugratama Cianjur Jawa Barat, Prosiding PKM-CSR 2 e-ISSN: 2655-3570, 648-651

Dina Rohmah 1, Dominicus Danardono Dwi Prija Tjahjana2, Suyitno2, Syamsul Hadi2, 2019, Peningkatan Pemahaman Gerakan Hidup Sehat Masyarakat Terhadap Covid-19 Di Wijirejo Pandak Bantul, Prosiding PKM-CSR 2 e-ISSN: 2655-3570, 652-658

Fajriani, S., Mustaniroh, S. A., Dewi, I. A., dan Subagiyo, A., 2021, KOKEDAMA Sebagai Inovasi Produk Jual Tanaman Hias Daun di Desa Wisata Sidomulyo, Kota Batu, Jurnal Tri Dharma Mandiri JTDM 1 (1), 25-30

Hadi, S., Ariawan, D., dan Arifin, Z., 2019, Pengembangan Desa melalui Optimalisasi Literasi, Pariwisata, Kesehatan, dan Sosial di Kecamatan Riung, Ngada, NTT, Jurnal SEMAR 8 (2), 39 - 48

Hadi, S., Wibowo, Triyono, J., Rujunia, L. O., dan Nasrianto, L. O., 2020, Peningkatan Potensi Wisata Desa Waginopo dengn Mengoptimalkan Sumber Daya Melalui Program Ekonomi Kreatif, Jurnal SEMAR 9 (1), 36 - 47.

Hadiwidodo, M., Sutrisno, E., Handayani, D. S., dan Febriani, M. P., 2018, Studi Pembuatan Kompos Padat Dari Sampah Daun Kering Tpst Undip Dengan Variasi Bahan Mikroorganisme Lokal (Mol) Daun, Jurnal Presipitasi: Media Komunikasi dan Pengembangan Teknik Lingkungan Hidup dan Kebencanaan 625 
Lingkungan 15(2), 79-85

Ismail, Y., 2019, Pengelolaan Sampah

Berbasis Masyarakat, Academics in Action Journal 1 (1), 50-63

Mahmudah, R., Abdullah., Rodiyah, H., dan Susilawati, 2020, Pemberdayaan Limbah Serabut Kelapa Menjadi Pobuke Berbasis Geometri Untuk Menaggulangi Tingkat Pengagguran Di Desa Senyiur", Jurnal Pengabdian pada Masyarakat Bidang Pendidikan, Sains, dan Teknologi 1 (1), 3343.

Mardwita, Yusmartini, E. S., Melani, A., Atikah, dan Ariani, D., 2019, Pembuatan kompos dari sampah organik menjadi pupuk cair Dan pupuk padat menggunakan komposter, Suluh Abdi: Jurnal Ilmiah Pengabdian Kepada Masyarakat 1 (2), 80-83

Muntafail, R., Nisa, K., Irmawati, D., Franandy P. A., dan Rakhmawan, I., 2020, Pelatihan Pembuatan Pupuk Kompos Dari Sampah Daun Kering, Universitas Negeri Semarang

Nurjazuli, Awiyatul, A., Juliana, C., Pertiwi, K. D., Samosir, K., Prasetyawati, P., dan Pertiwi, S., 2016, Teknologi Pengolahan Sampah Organik Menjadi Kompos Cair (Organic Waste Treatment Technology Toward Liquid Compost), Seminar Nasional Sains dan Teknologi Lingkungan II e-ISSN 2541-3880 Padang

Rosalinda, L., Wijayanta, A. T., Prabowo, A. R., dan Hadi, S., 2020, Peningkatan Pemahaman Tindakan Preventif Pencegahan Penularan Dalam Upaya Penanggulangan Pandemi Covid-19 Di Sorogenen Jagalan Jebres Surakarta, Prosiding PKM-CSR 3 e-ISSN: 2655-3570, 659-663

Sabrina, A. N., Hadiani, R. R, Arifin, Z., dan Hadi, S., 2020, Peningkatan Pemahaman Masyarakat Mengenai Covid-19 Menghadapi New Normal Di Cibeber Cilegon Banten, Prosiding PKM-CSR 3 e-ISSN: 2655-3570, 640-6
Sahil, J., Muhdar, M. H. I. A., Rohman, F., dan Syamsuri, I., 2016, Sistem Pengelolaan dan Upaya Penanggulangan Sampah Di Kelurahan Dufa-Dufa Kota Ternate, Jurnal Bioedukasi 4 (2), 478-487

Sari, S. L., Purwanto, H, Dewi, D. K., Pratiwiningtyas, L., Kurniasari, dan W. F., 2021, Pemberdayaan Masyarakat Melalui Pelatihan Budidaya Kokedama di Desa Sraten Kabupaten Ponorogo, Madaniya 2 (2), 107-114

Septriani, Y., dan Kasiyati, 2019, Meningkatkan Keterampilan Vokasional Membuat Kokedama Melalui Pembelajaran Discovery Learning Bagi Anak Tunarungu Kelas Vii Di Slb Luak Nan Bungsu Kota Payakumbuh, Journal of RESIDU 3 (22), 97-103

Shitophyta, L. M., Amelia, S., dan Jamilatun, S., 2021, Pelatihan Pembuatan Pupuk Kompos Dari Sampah Organik Di Ranting Muhammadiyah Tirtonirmolo, Kasihan, Yogyakarta, Communnity Development Journal 2(1), $136-140$

Sudiro, Setyawan, A., dan Nulhakim, L., 2018, Model Pengelolaan Sampah Permukiman Di Kelurahan Tunjung Sekar Kota Malang, Jurnal Plano Madani 7 (1), 106 - 117

Sulistyorini, L., 2005, Pengelolaan Sampah Dengan Cara Menjadikannya Kompos, Jurnal Kesehatan Lingkungan 2 (1), 77 - 84

Trahutami, S. I., 2019, Pengenalan dan Pelatihan Penanaman dengan Teknik Kokedama untuk Ibu-Ibu PKK, Jurnal Harmoni 3 (2), 36-39

Yuliarti, N. C., dan Dewi, S. R., 2021, Pelatihan Kewirausaan Kokedama Tanaman Obat Pada Ibu Rumah Tangga Di Desa Sukorwejo Bangsalsari Jember, Jurnal Pengabdian Masyarakat Manage 2(1), 51-54 